\title{
時間・空間スケールを考慮した異常降雨の グローバル解析に関する基礎的研究 \\ A BASIC STUDY ON GLOBAL ANALYSIS OF ABNORMAL RAINFALL IN VARIOUS SPATIOTEMPORAL SCALES
}

\author{
中北英一 1 ・義本欣司 2 \\ Eiichi NAKAKITA and Kinji YOSHIMOTO \\ 1正会員 工博 京都大学教授 防災研究所（干611-0011 宇治市五ヶ庄） \\ 2学生員 工学士 京都大学修士課程 工学研究科 (广606-8509 京都市左京区吉田本町)
}

\begin{abstract}
It is important to analyze what kind of abnormal rainfall has been occurring in the Globe. This research shows the followings. Spatiotemporal distribution of abnormality of maximum daily rainfall is a little different than maximum rainfall with longer time durations. Increases in time series of global percentage of area of abnormal rainfall has relation with ENSO. However, we can not say that global averaged rainfall is increasing. In case of Mississippi floods in 1993, seasonal abnormality gradually increased from spring to summer, and then, suddenly decreased in autumn. This kind of seasonal abnormality may also occur only by shifting of timing of rainy season such as monsoon. This would be vital for even those who are familiar with every-year large floods such as in the area of Mekong Delta. Also, in this case, averaged rainfall over 2degree mesh showed more abnormality than that point rainfall. This clearly implies that we must analyze abnormal rainfall considering spatiotemporal scales depending on size of target river basin.
\end{abstract}

Key Words : abnormal rainfall, extreme rainfall, global warming, ENSO, spatiotemporal scale

\section{1. 研究の背景と流域を考慮した降雨の異常さ}

近年世界各地で洪水などの異常降雨災害が発生して いる. 2002年には8月中旬にドイツ，チェコ，オースト リアで，9月初旬にはフランスで大規模な洪水災害が発 生した.この年は中国，メコンデルタ，バングラデ シュ, ロシア, 韓国といった他の世界各地でも深刻な 洪水災害が発生している. 社会基盤がより整備されて いると考えられるなか, 西欧地域での大災害には多く の人々が衝撃を受けた。 また 2000 年にはメコンデルタ において，1999年12月にはベネズエラにおいても大規 模な洪水災害が確認されている。 このように近年世界 各地では異常降雨災害が報告されており，これらを客 観的かつ総括的に解析する必要性が出てきた.

降雨の異常には，（1）「局地的」な「豪雨」の異常と， （2）「広範囲」な「持続的降雨」の異常の，2 種類が考 えられる.

日本では，(1)の「局地的」な「豪雨」の異常が問題 となる. 特に梅雨時や台風時には各地に大きな被害を もたらしている. 大陸大河川においては主要都市の存 在する地域を流れる大河川の支川流域や，わが国の中
小河川流域に「局地的」な「集中豪雨」が発生した場 合, 外水・内水氾濫が起こり, 都市に多大なダメージ を与える.

(2)の「広範囲」な「持続的降雨」の異常が問題にな るのは，大陸河川の本川などである，すなわち，大陸 河川のように流域面積が我が国のものより 1 ～2 オー ダー大きな河川流域の本川では，たとえ強度が弱くて も広い流域に異常に持続的に降雨がもたらされれば大 河川本川からの越水により洪水が生じる.

2002年のドレスデンの洪水は，（1），（2）の複合型で ある1). またメコンデルタの洪水は(2)の典型である2).

このように，降雨の異常さを評価するためには，降 雨の強度だけでなく, 降雨の持続期間や降雨の範囲を 含めて評価する必要がある.

中北・花房 ${ }^{3)}$, 4) は，降雨の「強度」と降雨持続期間と いう「時間的スケール」の $2 つ に$ 対する異常降雨指標に よって, いくつかの洪水災害時の降雨の異常さを評価 している.

本研究では, 中北・花房の異常降雨指標をべースに, 全球における異常降雨に対する検証をさらに進める. すなわち，降雨の「強度」と「時間スケール」からな 
るその指標に，さらに「空間的スケール」を考慮する. そのために，中北・花房らが地点雨量を対象としてい たのに対し, 本研究では地点雨量值を様々な空間ス ケールのメッシュ值に変換してその異常さを評価する.

\section{2. 降雨の異常さ指標}

降雨継続期間を考慮した降雨の異常さ指標について は，まず中北・花房らによって地点雨量に対して導入 された指標，すなわち年最大 $D$ 日雨量としての異常降雨 指標を使用する.

算出の手順としては，まず30年以上データのある場 合のみ，各地点それぞれについての年最大 $D$ 日雨量の従 う確率分布モデルを推定する. ただし，データの最大 長は100年を超える. 降雨継続期間については， $D=$ 1,3,7,15日とした. $D=31$ にいても調べたが確率分布 の強雨側の裾野のfittingが不良だったため除外している. 確率分布モデルとしては，正規分布，対数正規分布， Gumbel分布, 対数Gumbel分布, 指数分布の5種類を対 象とし，そのうち各地点の年最大 $D$ 日雨量が最も良く従 う確率分布モデルをその地点の年最大 $D$ 日雨量の従う確 率分布モデルとする. 各地点の年最大 $D$ 日雨量が従う確 率分布モデルの推定に当たっては図式推定法(graphical method)を用い，プロッティングポジション公式として ワイブル公式を用いた。 また，観測点数が多いため全 てに関して目視で判断するのは困難であるので，寶ら5) によって提案された確率分布モデルの適合性の評価基 準であるSLSC（標準最小二乗規準）を用いて，各地点 について最適な確率分布モデルを自動的に採択する.

次に， $T$ 年の地点 $i$ における年最大 $D$ 日雨量としての 異常降雨指標 $P_{D, i, T}$ を次のように定義する.

$$
P_{D, i, T}=\int_{r_{D, i, T}}^{\infty} f_{D, i}(x) d x
$$

ここで， $f_{D, i}(x)$ は地点 $i$ における年最大 $D$ 日雨量の従 う確率密度関数, $r_{D, i, T}$ は地点 $i$ における $T$ 年の年最大 $D$ 日雨量である. すなわち $P_{D, i, T}$ は $T$ 年の地点 $i$ にお ける年最大 $D$ 日雨量としての異常さであり，様々な 時間スケールを考慮した地点降雨の超過確率である.

\section{3. データのメッシュ化}

本研究に用いたデータは, Global Daily Climatology Network, Version 1.0 という, 全球32857ヶ所の観測点に おける日雨量データである. 解析するにあたっては,

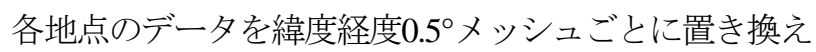
たものを最小空間スケールのメッシュ值とした. デー タをメッシュ化するにあたっては，1つのメッシュ内 に複数の観測点がある場合は観測值の平均值をその

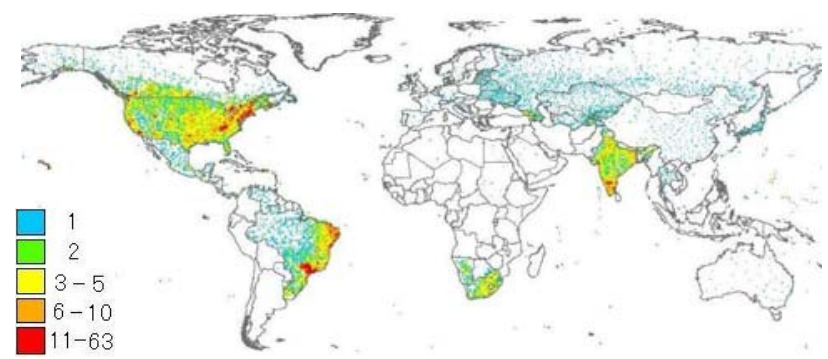

図-1 0.5メッシュ内の観測点数

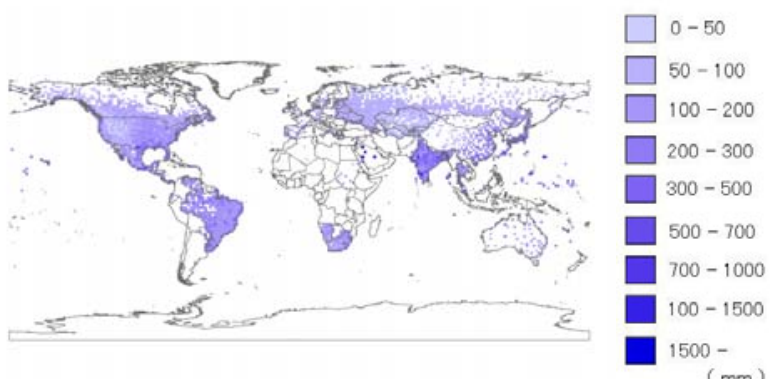

図-2 100年確率年最大日降雨量（地点データ）

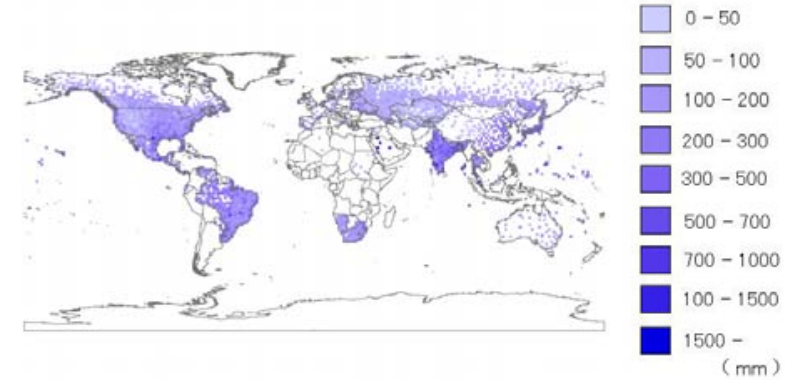

図-3 100年確率年最大日降雨量 （メッシュデータ）

メッシュにおけるデータとした. 0.5にメッシュ化した 時の観測地点の分布を図-1に示寸. $1^{\circ} \times 1^{\circ}$ のメシュュ スケール， $2^{\circ} \times 2^{\circ}$ のメシュスケールのメッシュ值の算 出方法としては, まずそれらのメッシュを4分割し, そ の分割した3メッシュ以上にメッシュ值が存在する場合 のみ，それらのメッシュ值の平均值をそのスケールの メッシュ值とした.

異常さ指標の計算は，2．で示した方法の地点雨量 をメッシュ值に置き換えることにより行う．また， メッシュ值が30年以上存在するメッシュのみ算定する

メッシュ化の利点としては以下の3点が挙げられる.

・観測点の空間密度の偏りを補正できる.

・同一メッシュ内に複数の観測地点がある場合は, 欠落している期間のデータを補い合える。 (データ長を長く取れる)

・ 様々な空間分布に関する解析をする際にサイズ の変更が容易である.

さて，メッシュのサイズが $0.5^{\circ}$ であことと，雨量 データが日雨量のものであることから，0.5メッシュ内 の複数の観測データの平均值をそのメッシュにおける 地点雨量とみなしても妥当であるとみなす。 もちろん

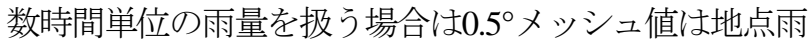
量とはみなせない. 
地点雨量としての0.5サイズのメッシュ化が妥当かど うかを調べるために，D=1,3,7,15日について全球におけ る50年確率と 100 年確率の降雨量を求めた。 寸なわち30 年以上データのある場合のみ各点の超過確率 $P_{D, i, T}$ が 0.02, 0.01 となる雨量 $r_{D, i, T}$ を算出し, グローバルマッ プに描いた. これらのことを地点データをもとにした 場合とメッシュデータをもとにした場合の両方を調べ て比較したところ，ほぼ同じ值を示していた。このこ とからも，地点雨量をメッシュに置き換えるにあたっ て特に問題がなかったことが言える．例として $D=1$ 日 についての100年確率降雨量について，地点データをも とに調べたものを図-2, メッシュデータをもとに調べ たものを図-3に示す.

\section{4. 空間分布としての降雨の異常さ傾向}

ここでは，各年の継続期間ごとに降雨としての異常 さの空間分布をグローバルマップ上で見ていく．異常 さ指標としては上で示した「年最大 $D$ 日雨量としての異 常降雨指標 $\left.P_{D, i, T}\right\rfloor$ を用い, 対象期間は1980年から 2000年までの21年間とした，異常さの空間分布を算出 する方法は以下の手順である.

1. $T$ 年の年最大 $D$ 日雨量の超過確率を各 $0.5^{\circ}$ メッシュ で算出する. $\quad(T=1980 \sim 2000, D=1,3,7,15)$

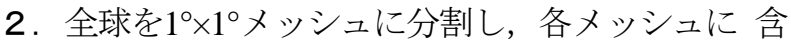
まれる観測データの中で最も超過確率 $P_{D, i, T}$ の值 の小さいものをメッシュ代表值としてグローバル マップ上に描く.

以上の手順で得られた年ならびに継続期間ごとの異 常さ分布のグローバルマップのうち，1986年の $D=$ 1,3,7,15日雨量の異常さ分布を図-4に示す. 特徵をまと めると以下の通りである.

（特徵 1 ）年最大3日で異常な場所は，年最大7日と年 最大15日でも異常となる傾向にある. しかし，年 最大1日に関しては他とあまり関連性のない分布を している傾向にある。

（特徵 2 ）年最大 1 日, 年最大 3 日, ・・, 年最大 15 日 と継続期間を長くするにつれ，各地に分散してい た異常さ分布は次第に塊になってくる傾向にある. これは，地点降雨の異常さの出現特性として，継続期 間 $D か ゙$ 短いほど局地的に現れる可能性が高く，継続期間 Dが長いほど広範囲に及ぶ可能性が高いことを表してい るといえる. 洪水をもたらす降雨の異常さの種類とし て「局地的な集中豪雨」の異常さと「広範な持続的降 雨」の異常さが考えられることを述べたが，このこと を裏付ける特徵であるともいえる.

\section{5. 時系列変化としての降雨の異常さ傾向}

\section{（1）異常降雨の面積割合}

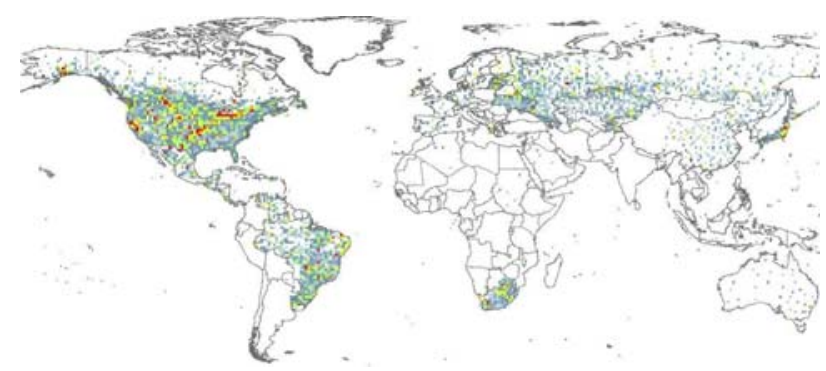

年最大 1 日

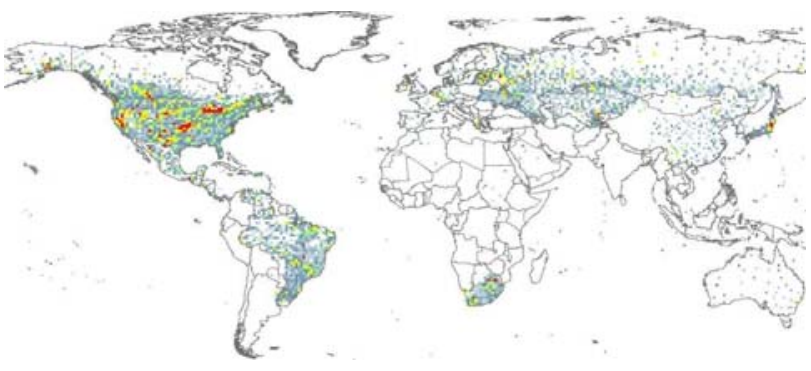

年最大3日

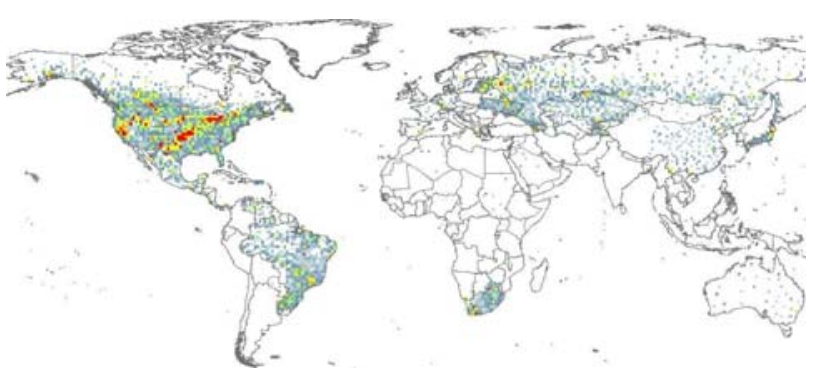

年最大7日

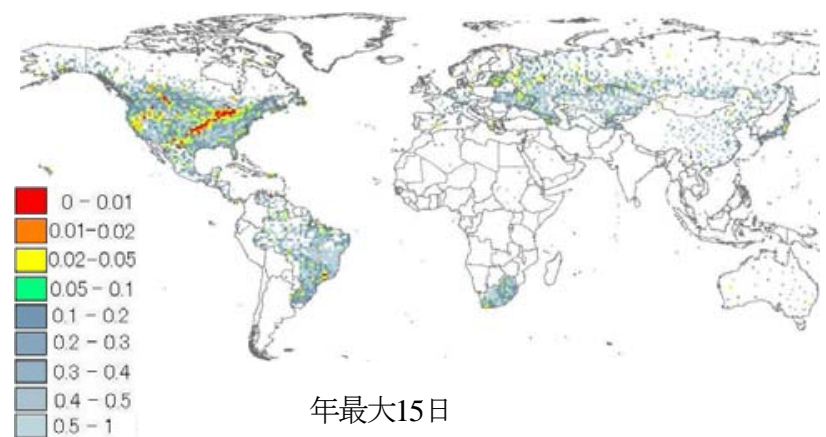

図-4＼cjkstart異常降雨指標のグローバル分布（1986年）

ここでは，年および継続期間ごとの全球的な異常さ の出現状況を別の指標をもって算定し，その傾向を調 ベる。ここでいう全球とは，地上雨量データが存在す る範囲という意味での全球である。全球の特徴を表す 指標として，異常な降雨があったメッシュの割合

$$
R_{D, T, x}=\frac{N_{D, T, x}}{M_{T}} \times 100 \quad(\%)
$$

を定義する．ここで $M_{T}$ はある $T$ 年にメッシュ值が存 在するメッシュ（0.5 メッシュ）の総数であり，Dに よらず $T$ のみに依存する. $N_{D, T, x}$ はある $T$ 年に $x$ 年確 率を超える年最大 $D$ 日雨量があったメッシュの総数であ 
る. すなわち, $R_{D, T, x}$ は $N_{D, T, X}$ の $M_{T}$ に対する割合とし て定義する. 言い換えれば，各年で異常降雨が発生し た全球における面積割合である.

次に, 指標 $R_{D, T, X}$ の時系列的な変化を調査する. 対 象期間としては1900年から2000年を選定し， $R_{D, T, 50}$ と $R_{D, T, 100}$ の 2 種類で全域を対象に調查する. 図-5は対象期 間内での $R_{D, T, 50}, R_{D, T, 100}$ の時系列変化を年単位で各 $D$ 毎 に示したグラフである. ここで $M_{T}$ は年 $T$ に依存する ので, 各年の観測メッシュ数を同時に示した. これら のグラフの特徵を以下に述べる.

（特徵 1 ） $\quad R_{D, T, x}$ は, 異常降雨の発生が地点間で無 相関であれば各年において $x$ 年確率を超えるメッ シュの空間的な出現率は $1 / x$ となるはずである.

図を見てみると, 一見 $R_{D, T, 100}$ は $1 \%$ 付近にばら つき， $R_{D, T, 50}$ は2\%付近にばらついているが，必ず しもそうでなく, 全球規模での空間相関の存在を 想定させる.

（特徵 2 ）各継続期間において, 特に1970年代後半 と1990年代後半で異常降雨の上昇傾向が見られる. したがって空間相関が強い可能性がある.

\section{(2) エルニーニョ現象との関係}

そこで，図-5の経年変化における，1970年代後半と 1990年代後半における異常降雨の発生面積割合の増加 と，エルニーニョ現象との関係について議論する.

異常降雨の発生が多い期間においてエルニーニョ現 象が発生しているのは1977年，1978年，1997年であり， その影響が強いと思われる1977年，1978年，1997年， 1998年にどこで異常降雨が発生しているかを調べた. それぞれの年について年最大1日雨量としての異常さの 分布を調べたが，1977年についての分布を図-6に示す. これらよりわかった事としては，1977年，1978年につ いてはインドにおいて異常降雨が多くのメッシュで発 生しており, アメリカにおいても異常降雨の発生した メッシュが散在している．また，1997年，1998年につ いては, アメリカにおいて異常降雨が多くのメッシュ で発生している. 1997年, 1998年のインドについては データが久損しているため不明である。これらの異常 降雨の発生域について調べたところ, エルニーニョ現 象の影響とされる多雨域() と同じ地域である。このこと より1970年代後半と1990年代後半における異常降雨の 面積割合の増加の原因として, エルニーニョの影響が 挙げられるということが言える.

\section{（3）全球平均降雨量との関係}

次に, 異常降雨の発生面積割合と全球における平均 降水量とに相関があるのかを検証する.

全球平均降水量の算出方法としては，あるT年におい て300日以上データのあるメッシュの年間降水量を求め, さらにそのメッシュにおける年間降水量を, データの
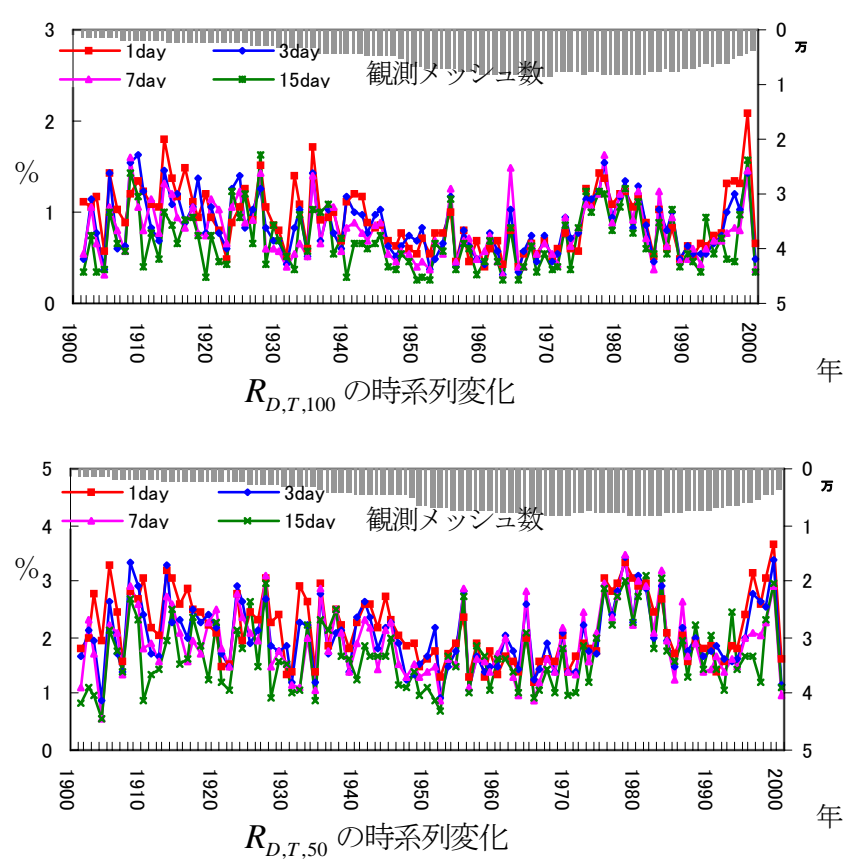

図-5 異常降雨のあったメッシュの割合の経年変化

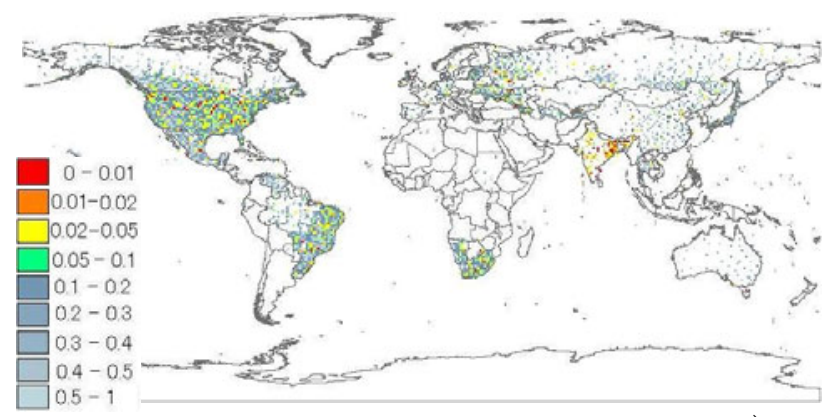

図-6 1977年の異常降雨指標の分布（最大1日雨量）

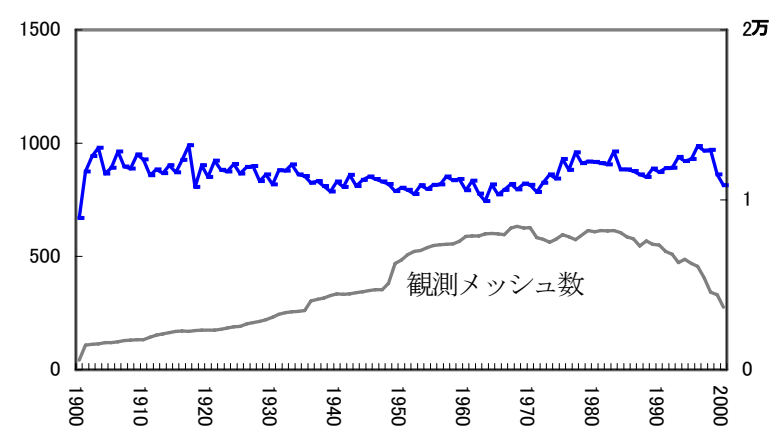

図-7 全球平均年降水量の経年変化

ある全メッシュにおいて平均する，そしてその合計值 を計算したメッシュ数（観測メッシュ数と呼ぶ）で除 したものを全球平均降水量とみなしている。このよう にして計算された平均降水量の経年変化のグラフを, 図-7に示す.グラフの縦軸は左が降水量を表し, 右が 観測メッシュ数を表している.

この図-7から, 異常な降雨の面積割合が高かった 1999年に平均降水量が下がっているなど，異常な降雨 の面積割合の増加とともに平均降水量が増加している 
などの相関はないことがわかる，しかし，図-7におけ る平均降水量は計算に含まれるメッシュの変化が大き いため, 計算に含まれる多雨域や少雨域割合の変化に よる変動に大きく左右されてしまう。そこで，次のよ うに再計算を行った。 2000年に観測值が得られたメッ シュだけを用いて同様の計算を行った結果を図-8に示 寸. 図-7と同様に，図-8からも，異常な降雨のあった 地点の面積割合の時間変化と平均降雨量の変化には特 に相関が見られないことが分かった. 寸なわち，D日雨 量としての異常降雨量が発生する頻度の大小と, その 年の全球での降水多䓖とは相関が無く, かつ大きな卜 レンドもないということがここでの結論である.

\section{6. 他の視点での異常降雨指標}

\section{（1）空間スケールを考慮した異常降雨指標}

ここでは，空間的スケールを考慮した雨量として， 空間スケールの異なるメッシュでの平均值に対して異 常降雨指標の特徽を調べる.

1゚メッシュスケールと2゚メッシュスケールに対する 100 年確率に対応する年最大 1 日降雨量を図 -9 に示す.

$1^{\circ}$ メッシュスケールでは一部描かれない部分が存在す る. その理由はそれぞれのスケールのメッシュ内での 空間平均的な降雨を対象とするので, 各メッシュ内に 分散して位置する複数の観測点が存在する場合のみを 対象としているためである. それらを地点（0.5メッ シュ）における100年確率降雨量（図-2, 図-3）と比較 する. 気象擾乱のスケール階層構造からすると当然の ことであるが，地点からスケールが大きくなるにつれ て雨量の值が減っている. 同様に, 空間スケールが大 きくなるにつれ異常さ分布が大きな塊状になること， すなわち, 長期間の降雨の異常さは広範囲に及ぶこと を示している結果が得られた.

次に空間スケールを考慮した事により，実際の洪水 での降雨の異常性をより顕著に示せた例として, ミシ シッピー川で大洪水が発生した1993年におけるアメリ カでの異常降雨への適用例を図-10に示寸.1993年のミ シシッピー川大洪水を引き起こした降雨は広範囲な持 続的降雨に分類され， $0.5^{\circ}$ メッシュにおける最大 15 日雨 量の異常さよりも, 20メッシュスケールでの異常さの方 が大きかったことを示している．注意を要するが，こ れは当然のことではない. 残念ながら今回利用した データセットにはデータが存在しないので解析はでき なかったが， 1.で述べたように，2002年8月のヨー ロッパ洪水の特にドレスデン上流域全体としては, こ のミシシッピー川洪水と同じように，広い空間スケー ルの降雨の方がより異常であった可能性が高い》.

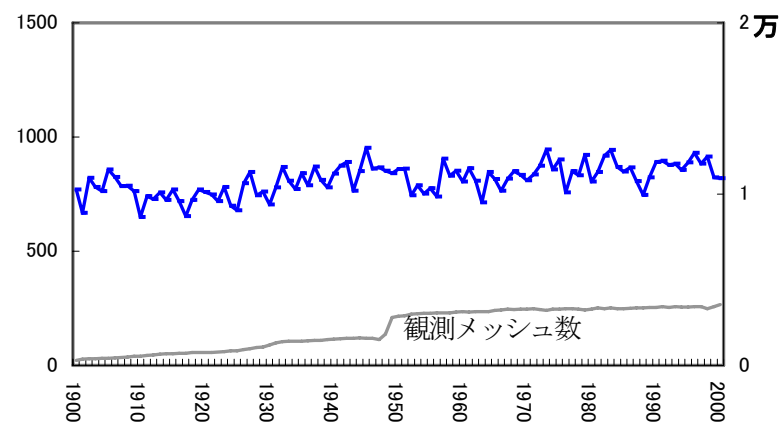

図-8 2000年に観測された点の平均年降水量の経年変化

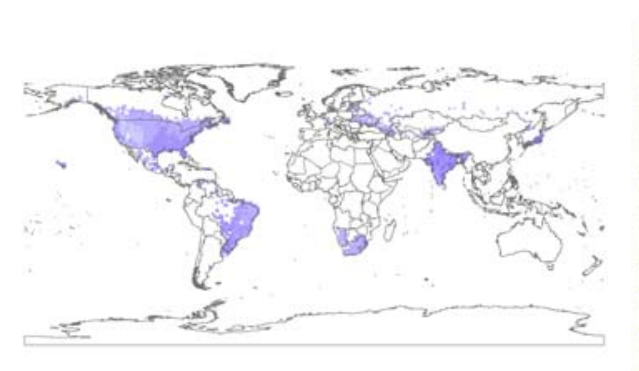

$1^{\circ}$ メッシュスケール

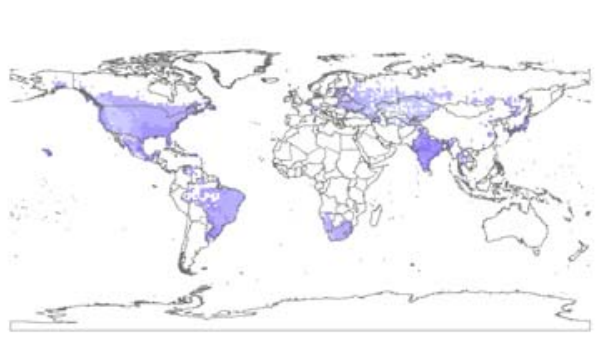

$2^{\circ}$ メッシュスケール

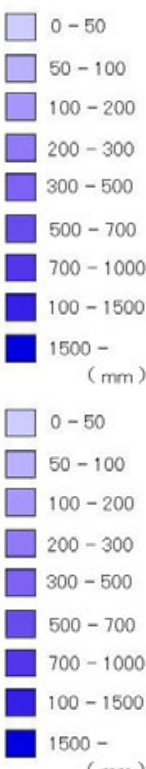

図-9＼cjkstart空間スケールを考慮した100年確率1日降雨量

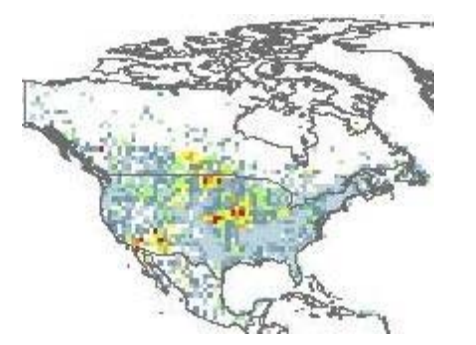

$0.5^{\circ}$ メシュ
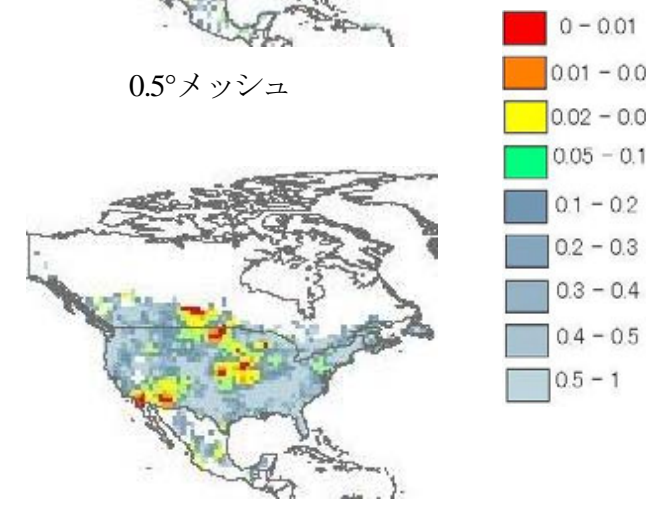

$\square 001-002$
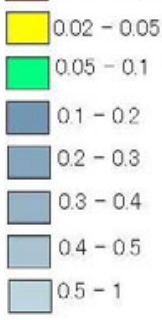

2゚メッシュ

図-10 1993年の年最大15日雨量としての異常降雨指標の分布 


\section{（2）季節ごとの異常降雨指標}

ここまでは年最大 $D$ 日雨量としての降雨の異常さを調 べてきたが，季節ごとの異常さも重要であり，ここで は季節最大 $D$ 日雨量としての降雨の異常さについて述心 る. すなわち, 1年を冬(1-3月), 春(4-6月), 夏(7-9月), 秋(10-12月)に分割し, 季節最大 $D$ 日雨量としての異常さ 指標を，それぞれの季節ごとに算定する.

図-11は，この指標を1993年のミシシッピー川洪水一 適用したうち, 地点としての最大7日雨量としての異常 さを示寸，ただし，黒線で囲んだ領域は，特に大規模 な洪水となったセントルイスへの出水に影響を及ぼす 上流域をおおよそ示している。この図によると春から 夏にかけて徐々に異常性が増加し, 秋になると突然異 常さが消滅したことを表している. 図-10では年最大 15 日雨量の異常さを示したが，これが主に，春〜夏の異 常さによってもたらされていることを示している.す なわち, ミシシッピー川洪水の事例にとどまらず, 全 球的にどの季節での異常さが出現したかの視点, 解析 の重要性を物語っている.

さて，季節ごとの異常さは2つの要因でもたらされる ことに注意すべきである.すなわち,

（1）年々の異常さと同様，毎年その季節に生じる多 雨が異常であった場合,

（2）毎年ある季節にもたらされる通常の多雨が，た またま季節的に早いまたは遅い時期にもたらさ れた場合,

である.1993年のミシシッピー川洪水は(1)の異常さに よる. 図-10の年最大15日雨量の異常さ分布がそれを示 している. また，2002年のヨーロッパ洪水もそうであ $ろ^{1)}$. 翻って，2000年のメコンデルタの洪水の異常さは 主に(2)の要因にて生じている. 寸なわち, モンスーン の雨季による出水が早目に始まったのが最大の要因で ある2). 実際，いくつかの継続時間の年最大降雨量はそ れほど異常ではなかっだ2. メコンデルタでは, 毎年同 じ時期に到来寸る洪水を前提として, 農業を含めた年 内の生活パターンを形成している。しかし，たとえ例 年通りの規模の洪水でもそれが季節はずれのものとな ればきわめて人々にとっては異常となる，そういう意 味で, (2)の意味での季節異常さの出現特性の解析もき わめて重要である.

\section{7. 結論}

以上，異常降雨の解析のあり方ならびに，それを ベースに定義した異常降雨指標を用いて異常降雨の解 析をいくつかの側面から行い，側面ごとの異常さの特 徵を定義した指標が示していること，それらが地球規 模で関連している可能性があること, 側面により異常 さが異なることなどを示した，今後は，各側面ならび
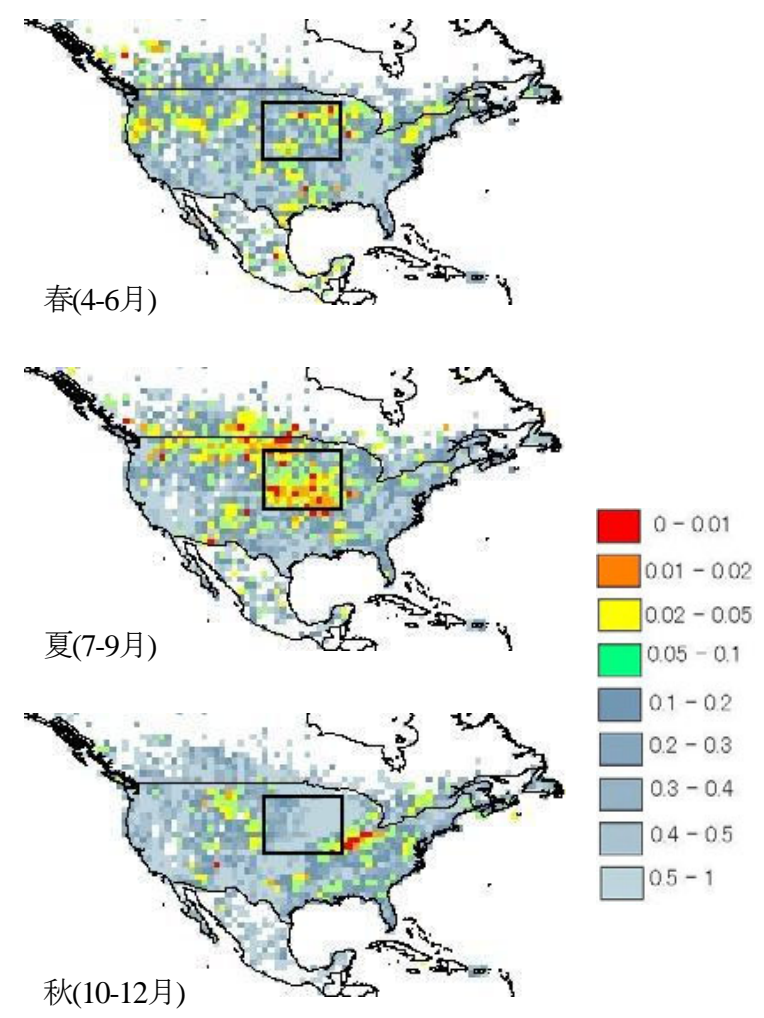

図-11＼cjkstart季節最大7日雨量の異常さ傾向（1993年）

にその統合化に向けてのより深い解析を行ってゆく予 予定である.

\section{参考文献}

1) 2002年ヨーロッパ水害調查団・(社) 土木学会 : 2002年 ヨーロッパ水害調査一報告書一, 112 pp.., 2003.

2) 土木学会水理委員会 : メコン河洪水氾濫調查報告書, 2000年11月, 84 pp., 2001.

3) 中北英一・花房大輔 : 様々な時間・空間スケールと流域 特性を考慮した異常降雨のグローバル解析，第12回地球 環境シンポジウム講演論文集, 土木学会, pp241-246, 2004.

4) Nakakita, E. and D. Hanafusa: A study on global analysis of abnormal rainfall through various spatiotempral scales and basin characteristics, Proc. of Int. Conf. on Monitoring, Prediction and Mitigation of Water Related Disasters, Kyoto, pp.7-12, 2005.

5) 寶馨・高棹玩馬・清水章 : 琵琶湖水文データの基礎的分 析, 京都大学防災研究所年報, 第29号B2, pp.157-171, 1986.

6) 気候影響・利用研究会編, 日本農業気象学会・気候変化 影響研究部会協力: エルニーニョと地球環境, 改訂増補 版, 成山堂書店, 2001.

7) 中北英一: 欧州災害について一気象・水文状況と災害の 実態一, 河川, No.679, pp.14-23, 2003. 